\title{
O discurso psiquiátrico e a ideologia colonial na África britânica.
}

\author{
Psychiatric Discourse and Colonial Ideology in British Africa.
}

\author{
Gisele Silva Santos ${ }^{1}$
}

RESUMO

Os estudos psiquiátricos produzidos por europeus durante o período colonial sobre disfunções mentais entre os africanos colaboram para uma reflexão sobre as normativas e paradigmas das ciências humanas. Considerando a afirmação de michel foucault de que a loucura nas sociedades ocidentais modernas se trata de um discurso constitutivo de relações de poder, o presente artigo investiga como os estados coloniais britânicos na áfrica procuraram exercer poder e controle por meio de teorias etnopsiquiátricas e seus discursos. Estudos psiquiátricos na áfrica colonial abrem a possibilidade de interpretação do que era considerado patológico e normal naquele contexto e oferecem significativas evidências sobre a ambiguidade nas conclusões alcançadas por seus médicos e pesquisadores. Este ensaio explora um conjunto de produções psiquiátricas entre os anos de 1920-1960, período marcado pelo desencadeamento de uma série de movimentos nacionalistas e pró-independência na áfrica colonial britânica. O principal objetivo é elucidar a aliança entre a medicina ocidental e a autoridade colonial a fim de promover o controle das forças coloniais sobre a população africana. Concluiu-se que durante o processo de descolonização na áfrica, quando a força dominante estava em constante atrito com a população negra nativa, o conhecimento psiquiátrico ganhou o papel de elementolegitimador da missão civilizatória.

Palavras-chave: África colonial britânica, Etnopsiquiatria, Discurso científico, Movimentos nacionalistas, Ideologia colonial.

1Professora do Departamento de História da Universidade Paranaense - UNIPAR - campus Cascavel. . Mestre em História das Ideias pela Universidade de Londres - Birkbeck College, mestre em História Social pela Universidade Estadual Paulista - UNESP - campus Júlio Mesquita, Assis. 


\section{ABSTRACT}

Psychiatric studies produced by Europeans during colonial period on African mental disorders contribute to a reflection over human sciences' normative and paradigms. Considering Foucault's statement that madness in modern western society can be defined as a discourse constitutive of power relations, the article investigates how colonial states exercised power through psychiatric theories and its discourses. Psychiatric studies in colonial Africa give the means to an interpretation of what was considered normal and pathological in that context and provide significant evidence about the ambiguity in the conclusions reached by those physicians and researchers. The essay explores a set of psychiatric writings produced during 1920-1960, a period marked by the triggering of nationalist and pro-independence movements. The main goal here is to shed light on the relationship between the Western medicine and colonial authority and demonstrate how this alliance promoted the control of colonial powers on the African population. It was concluded that during the process of decolonization in Africa, when was the ruling force constantly in disagreement with the native black population, the psychiatric knowledge played the role of legitimizing element of the civilizing mission.

Keyword: British Colonial Africa, Ethnopsichiatry, Scientific discourse, Nationalist uprisings, Colonial ideology.

Para o ativo, a objetividade está sempre voltada contra ele.

(FANON, 1967, p.77)

Diferentemente de Frantz Fanon que argumentou que o processo de colonização alimenta psicopatologias e a necessidade de liberar violência entre os nativos, ou Otávio Mannoni que defendeu que a colonização, enquanto processo, se sustenta por meio de noções patológicas e internalizadas de dependência por parte do sujeito colonizado em relação ao colonizador (MANNONI, 1956) este artigo explora o discurso psiquiátrico colonial produzido entre as décadas de 1920 e 1960 por etnopsiquiatras nas colônias britânicas de Niassalândia, Nairobi, Rodésia do Sul, Quênia e África do Sul, localizadas na África Meridional. Este trabalho procura demonstrar como a objetividade científica pode ser pensada enquanto um caminho na produção de estereótipos, e mais precisamente, demonstrar as formas como esses últimos podem ser usados contra o sujeito nativo das colônias.

A etnopsiquiatria, assim como a sociologia, a antropologia e outras ciências, compõem o conjunto de disciplinas filhas do processo de colonização da África no século XIX, pelos europeus. Isto significa que foi o neocolonialismo europeu que proveu o cenário social em que essas ciências emergiram. Torna-se impossível, portanto, separar a história dessa disciplina dos investimentos coloniais. As práticas e as produções de etnopsiquiatras são recorrentes na primeira metade do século XX e desaparecem, não coincidentemente, ao passo em que as condições sociais sobre as quais elas emergiram foram se desconstituindo. Ao rever a história dessa ciência faz se importante considerar que o neocolonialismo, em si, também não perdurou por muito tempo. 
Desde as famosas censuras anticoloniais feitas pelo psiquiatra e filósofo da Martinica Frantz Fanon ${ }^{2}$, as patologias mentais na África colonial tem sido tema de muitas pesquisas historiográficas. Nas últimas décadas, estudos históricos sobre os usos da literatura etnopsiquiátrica ao longo do período colonial africano, tem renovado os debates em torno da importante relação entre o conhecimento médico-psiquiátrico e o domínio colonial. ${ }^{3}$

Neste artigo, de maneira similar às novas abordagens, intenciona-se associar os estudos psiquiátricos e sua literatura ao contexto político colonial, afim de examinar como as relações entre colonizador e colonizado se refletia nas teorias psiquiátricas. Mais precisamente, busca-se demonstrar como o trabalho desses etnopsiquiatras falhou em compreender as disfunções mentais dos nativos, mas foi eficiente ao representar a mentalidade de uma elite minoritária colonial europeia.

A literatura etnopsiquiátrica do final do século XIX e das primeiras décadas do século $\mathrm{XX}$ estava repleta de tentativas pelas quais pesquisadores procuravam explicar as principais causas do atraso no desenvolvimento do cérebro dos africanos por meio de análises de seu peso e sua estrutura. Na aurora do neocolonialismo, o discurso médico etnopsiquiátrico operava localizando as diferenças do corpo dos "homens primitivos"; não somente lapidando essas diferenças nos moldes patológicos, como também tratou de naturalizar essa noção. Já na segunda metade do século XX, a noção biológica de raça esteve sob o ataque de teorias médico-liberais que, desconfortáveis diante da "incorporação" da diferença, optaram por perseguir essas variações na mentalidade e no comportamento social dos nativos da colônia, presumindo ter encontrado a razão do retrocesso dos povos africanos em sua personalidade ou cultura.

A literatura produzida no âmbito da etnopsiquiatria deriva principalmente do trabalho clínico conduzido por médicos psiquiatras junto de seus pacientes em asilos africanos construídos pelas autoridades coloniais a partir de programas de saúde pública. Todos os estudos psiquiátricos explorados no presente artigo foram comissionados pelas autoridades coloniais.

\footnotetext{
${ }^{2}$ Frantz Fanon (1925-1961)foi ao mesmo tempo psiquiatra, ensaístae militante político ao lado da Frente de Libertação Nacional daArgélia (FLN), coma qual compartilhava a causa independentista. Martinicano, faz parte do grupo de intelectuais negros cuja importância a França tem dificuldade em reconhecer, embora tratem de uma história comum a todos. Anticolonialista radical, de escrita altamente literária e retórica, contribuiu para aclarar não só a história, mas também reflexões e debates contemporâneos. Para melhor conhecer a interpretação psicanalítica de Fanon sobre o racismo colonial. (FANON, 2008).

${ }^{3}$ Estudos como os de Megan Vaughan sobreo hospício de Zomba em Niassalândia, por exemplo, oferece grande contribuição para a compreensão do discurso médico-psiquiátrico elaborado de acordo com os fundamentos da ideologia colonial. (VAUGHAN, 1991). Jonathan Sadowsky (1997) oferece ricas fontes sobre a teoria psiquiatra produzida na Nigéria colonial. O autor demonstrou como essa era relativamente liberal, isto é, em certa medida menos ligada às formas mais virulentas de racismo, embora estivesse limitada por noções etnocêntricas e evolucionistas. Outro importante estudo sobre etnopsiquiatria na África Colonial é o de Jock McCulloch que procurou demonstrar como esses médicos, mesmo trabalhando em isolamento intelectual, apresentavam características ideológicas muito semelhantes em seus trabalhos. (MCCULLOCH, 1993).
} 
Esse trabalho é pautado principalmente nas publicações em periódicos acadêmicos de etnopsiquiatras que obtiveram grande projeção entre o corpo médico britânico, colonial e europeu, após suas publicações. São eles: Horace Shelley, Willian H. Watson, H. L. Gordon, F. W. Vint, B. J. F. Laubscher e J.C. Carothers. Esse corpo médico era composto por profissionais nascidos na Europa, com exceção de Carothers que havia nascido na África, todavia membros das comunidades de europeus nas colônias africanas e que atuaram como médicos etnopsiquiatras em pelo menos uma das colônias britânicas que definem o recorte espacial desse trabalho: Niassalândia, Rodésia do Sul, Quênia e África do Sul. Alguns desses especialistas, como era o caso de Shelley e Watson eram psiquiatras qualificados que trabalhavam diretamente com pacientes psiquiátricos, outros, como Gordon, Vint e Carothers eram médicos com um interesse em psicologia, mas com pouca experiência clínica e outros ainda eram amadores que possuíam paixão por alguma escola de pensamento como a psicanalise, por exemplo. ${ }^{4}$

Os autores da literatura etnopsiquiátrica abordada nessa pesquisa trabalharam de maneira isolada, em contextos díspares e apresentavam diferente fundamentação filosófica em seus trabalhos. No entanto, segundo Jock McCulloch em Colonial psychiatry and 'The African mind', esses etnopsiquiatras compartilhavam de um ponto de vista muito específico em comum com as sociedades colonizadoras brancas e europeias:

[...] Eles eram conduzidos por um desejo de segregação da maioria negra, entretanto, esse desejo estava comprometido por uma dependência da mão-de-obra negra. Na Rodésia do Sul em 1936, quando a população de brancos europeus contabilizava 56 mil pessoas, havia praticamente a mesma quantidade de trabalhadores domésticos negros registrados. (MCCULLOCH, 1995, p. 4)

Segundo McCulloch, a importância do discurso da diferença, enquanto característica marcante da literatura médico-psiquiátrica na África colonial, pode ser compreendida através da forma como a "diferença" era operada diretamente na vida cotidiana na colônia. $\mathrm{Na}$ esfera legal, por exemplo, a diferença é notável nas leis que negavam direitos civis à população nativa, ou proibitivas, como no caso da África do Sul e da Rodésia do Sul, onde o contato sexual inter-racial era ilegal. Em termos de políticas públicas e econômicas, é também caro ressaltar que a diferença era explícita quando a maioria negra era privada do direito de participação política e tinha sua mão-de-obra explorada compulsoriamente, ao

\footnotetext{
${ }^{4}$ As informações oferecidas sobre etnopsiquiatras citados foram retiradas de estudos realizados por Jock McCulloch que fez um verdadeiro levantamento sobre o corpo de etnopsiquiatras queatuou nas colônias britânicas na África. (MCCULLOCH, 1993).

${ }^{5}$ Todas as citações extraídas de fontes primárias ou secundárias escritas em inglês foram traduzidas por mim.
} 
passo que a minoria branca detinha, não somente o poder administrativo, como o controle dos bens de produção. (MCCULLOCH, 1995, p. 5-7).

De acordo com Megan Vaughan, um profundo 'medo colonial' foi a causa principal que propulsionou o financiamento de todas essas pesquisas e estudos sobre "A mente dos africanos" por parte das autoridades coloniais. Segundo a autora, esse medo passou a ser mais evidente nos anos de 1930, quando a "desintegração" da estrutura "tradicional" das sociedades africanas ameaçava a prevalência do controle social. Através do governo indireto, as autoridades coloniais e as comunidades europeias na África britânica acreditavam que poderiam conter o choque cultural causado pelas mudanças trazidas pelo neocolonialismo se os povos nativos pudessem continuar obedecendo seus líderes tradicionais e seguindo suas regras tradicionais. Os africanos seriam governados pelo costume que, por sua vez, receberia uma legitimação oficial. (VAUGHAN, 1991, p. 109). Como demonstrou Martin Chanock, havia uma série de ambiguidades no sistema de governo indireto através dos costumes. Para Chanock, a retórica da civilização, mais que qualquer outra coisa, viria a representar o dilema essencial do contexto colonial. A civilização, ao mesmo tempo que apresentava inúmeras benesses que tornavam sua implantação à sociedade colonial inadiável, era também perigosa para a manutenção da ordem hierárquica social. (CHANOCK, 1987). De fato, a ideia do neocolonialismo como uma missão civilizatória nunca foi erradicada durante todo o período colonial africano, ao contrário, ela foi retomada fortemente nos estudos psiquiátricos coloniais durante os períodos pós e entre guerras.

A noção rousseauniana ${ }^{6}$, disseminada pelos alienistas do século XIX, de que o homem nativo dos territórios coloniais era o "bom selvagem" cujos valores morais haviam sido desvirtuados durante o processo civilizatório abriu possibilidades para novas interpretações como as desenvolvidas pelos etnopsiquiatras na África da primeira metade do século XX. A combinação de uma ciência psiquiátrica de grande prestígio, com um racismo colonial europeu e suas ideologias de classe dominante, transformaram o status do homem nativo da colônia de "bom selvagem", "exótico" e de personalidade simples para alguém de cérebro cru, atrasado e biologicamente não evoluído. A ideia de que os nativos eram especialmente vulneráveis aos efeitos da civilização era agora construída, não mais sobre o argumento dos efeitos negativos do processo civilizatório, mas pelo prisma das capacidades inferiores do cérebro pouco desenvolvido dos nativos.

\footnotetext{
${ }^{6}$ Em Rousseau (1978, 1993), desenvolveu e explorou a metáfora do "bo m selvagem" que pode ser entendida como uma crítica do filósofo direcionada aos poderes exacerbados da razão e da ciência que ele foi o primeiro a questionar em plena vigência do iluminismo. Para Rousseau, certas normas sociais estabelecidas nos grandes centros urbanos afastaram o homem de sua verdadeira natureza. A teoria da bondade natural do homem de Rousseau deteve grande influência sobre o pensamento de alienistas como Esquirol, Moreau de Tours, Griesinger e Lombroso que argumentavam emfavor de uma relação estreita entre civilização e doença mental entre os povos "primitivos". A ideia de que a insanidade era rara entre os povos "primitivos" e que o contato dos mesmos com a civilização havia desencadeado uma série de transtornos mentais entre esses povos, foi uma tendência que prevaleceu como importante elemento do discurso alienista do século XIX. (ODA; BANZATO; DALGALARRONDO, 2005).
} 
Enquanto etnopsiquiatras alternaram, ao longo do tempo, sua forma de explicar a inferioridade dos africanos, ora através da diferença biológica, ora através da diferença cultural, a releitura de críticos $\operatorname{modernos}^{7}$ dessa ciência evidenciam que análises fundamentadas na diferenciação biocultural consagram um tipo de ciência totalizante, universalizante, que implicam em posições estanques muito próprias de um grupo social em específico: a elite colonial.

\section{Os Neuropsiquiatras}

Michel Foucault explorou a noção de "biopoder" e sua dinâmica tanto no corpo dos indivíduos quanto no corpo social como um todo. Através da análise de uma série de discursos e práticas, desde a criação das prisões até a invenção da sexualidade, Foucault demonstrou como o corpo na sociedade moderna, tem se tornado tanto um lugar como um elemento constituinte de relações de poder. (FOUCAULT, 1989) O principal foco desse trabalho é demonstrar, de acordo com a abordagem de Foucault, como discursos etnopsiquiátricos sobre transtornos mentais entre os nativos na África colonial precisam ser vistos como parte constituinte dos problemas que eles descrevem, como eles também refletem, mesmo que de forma indireta, as circunstâncias políticas e materiais externas ao universo da medicina.

Apesar dos muitos paralelos com a história da definição e do confinamento dos insanos na Europa moderna, as especificidades da vida colonial precisam ser consideradas a fim de se escrever a história da loucura na África colonial. Segundo Vaughan, enquanto para o Estado Moderno Europeu o corpo médico-psiquiátrico apresentava importante papel social, pois era capaz de identificar os insanos como também tinha o poder de encarcera -los, o caso da psiquiatria colonial era diferente. Para esta autora, a necessidade que os europeus da era moderna possuíam de rotular o "Outro" ${ }^{8}$ como insano ou leproso a fim de distancia-lo da sociedade civil organizada, era menos urgente no caso do contexto do neocolonialismo. Na visão do homem europeu branco, ocidental e colonizador, cada indivíduo nativo da colônia

\footnotetext{
${ }^{7}$ Além de Vaughan, Sadowsky e McCulloch, outros importantes nomes podem ser incluídos aos numerosos estudos sobre psiquiatria colonial como os de Comaroff, John e Comaroff, Jean (1987), Dubow (1993) e German (1987). ${ }^{8} \mathrm{O}$ termo o "Outro" está diretamente associado ao conceito filosófico e também antropológico de alteridade. De acordo com Abbagnano, um dos princípios fundamentais da alteridade é que o homem na sua vertente social tem uma relação de interação e dependência com o outro. Assim, as relações com o Outro permeiam os patamares do reconhecimento perante as diferenças. Conforme Abbagnano (2007), o termo significa "ser outro, pôr-se ou constituir-se como outro" e sua abordagem abrange também parâmetros psicológicos e cognitivos, em que a capacidade de apreender o "Outro" em sua plenitude de direitos e, principalmente de diferenças, têm servido para atenuar conflitos diante das relações pessoais e sociais.
} 
já era reconhecido, em algum sentido, como o "outro". Para esta historiadora, a grande problemática a ser explorada na literatura etnopsiquiátrica produzida na África colonial seria o esforço desse corpo médico em definir as especificidades do estado mental de normalidade dos africanos e evidenciar as diferenças entre europeus e africanos normais e, por fim, promover a patologização da "mente africana normal". (VAUGHAN, 1983, p. 20-22). Em 1935 os psiquiatras Shelley e Watson, dois médicos oficiais do Governo de Niassalândia, publicaram os resultados de uma investigação comandada por ambos sobre disfunções mentais entre os nativos daquele protetorado. (SHELLEY; WATSON, 1936). No hospício de Zomba eles encontraram uma alta porcentagem de pacientes sofrendo de "alucinações esquizofrênicas", as quais eles classificaram em duas categorias: as de "tipo europeu" e as do "tipo nativo". Exemplos do primeiro tipo de alucinações era dado conforme segue:

Homem muito rico e construiu o asilo com seu capital.

O céu e a terra eram separados e ele gostaria de unificá-los.

É proprietário do Porto Herald e é casado com uma mulher branca.

É proprietário de uma mina de ouro, é filho de um rei, é um inglês.

Vive em uma propriedade pública doada a ele pelo governador precedente.

É o comandante de um grande exército. (SHELLEY; WATSON, 1936, p. 715-716).

As alucinações do "tipo nativo" eram aparentemente menos comums, mas Shelley e Watson (1936, p. 717) ofereceram exemplos:

É um leão, quer matar pessoas e comê-las.

Pensava que ele era um cachorro latindo e que gostaria de morder pessoas.

Sua esposa estava cometendo adultério.

Na África colonial, definir e categorizar um louco era uma tarefa complexa. A maior parte dos oficiais da colônia permitiam que a maioria daqueles diagnosticados como insanos permanecessem junto de suas e comunidades, desta forma, o Estado não teria 
responsabilidade sobre eles. Todavia, os criminosos insanos eram classificados como uma categoria distinta e com a finalidade de separá-los do resto da sociedade foram criados os asilos para lunáticos.

Em 1910, o asilo para lunáticos Zomba foi inaugurado como uma ala da prisão central do protetorado britânico de Niassalândia, com o propósito específico de segregar os criminosos insanos dos outros prisioneiros. Em 1930, o asilo contava com 84 internos, dos quais 57,1\% eram insanos que haviam cometido algum tipo de crime. $O$ restante da população do asilo não era de infratores, mas apresentava algum tipo de transtorno mental, tais como demência, psicoses, paralisias e etc. Shelley e Watson haviam examinado individualmente todos os internos do asilo. Todavia, esses psiquiatras concentraram seus estudos nos internos criminosos. Os médicos procuraram classificar esse grupo dentro de duas das categorias mais recorrentes: A esquizofrenia atingia $35.7 \%$ dos pacientes do asilo, e os atingidos por "psicoses afetivas" constituíam 21.4\% da população total. (SHELLEY; WATSON, 1936)

Os médicos psiquiatras acreditavam que a incidência do número de insanos em Niassalândia estava aumentando especialmente entre a população educada. A evidência que eles usaram para apoiar seu argumento já havia sido explorada pelos alienistas do século XIX: A ideia de que os indígenas nativos eram especialmente vulneráveis aos efeitos da civilização - dado que o seu cérebro mais primitivo não resistiria aos efeitos prejudiciais de um tipo mais desenvolvido de sociedade. ${ }^{9}$ Ao descobrirem que $24 \%$ dos internos do asilo eram provenientes da etnia Yao, Shelley e Watson afirmaram que era compreensível que esse povo, com contato mais íntimo e direto com os europeus, apresentasse altos índices de loucura se comparado aos demais africanos. Somente $15 \%$ dos pacientes eram mulheres, fato que levou os médicos a deduzirem "mulheres não entram em contato direto com europeus e suas mentes são desprovidas do estímulo que a mente masculina encontra através de tal contato". (SHELLEY; WATSON, 1936, p. 710-714).

Aparentemente, para esses dois médicos, os internos do asilo estavam divididos entre aqueles cuja doença mental poderia ser explicada por questões ligadas a sociedade "tradicional" (nativa) e a categoria mais numerosa composta por homens que haviam se tornado loucos, a partir do seu contato com a sociedade "moderna". Esses dois grupos puderam ser diferenciados não somente pelo histórico educacional dos pacientes, mas pelo conteúdo de suas ilusões, as quais eram de caráter "europeu" ou "nativo". De acordo com esses dois médicos, a cultura dos colonizadores não teria afetado exclusivamente o conteúdo das ilusões dos nativos insanos, mas que o contato com a sociedade europeia havia ocasionado doenças mentais entre os indígenas. Shelley e Watson focaram sua atenção no grupo que eles definiram como esquizofrênicos:

${ }^{9}$ Sobre os alienistas da colônia do século XIX e suas teorias a respeito da saúde mental do homem "primitivo", ver nota número 4 . 
[...] seus distúrbios sexuais, seu tipo europeu de ilusões, sua atração por desrespeitar a propriedade privada, aparentam manifestar um comportamento mental mais semelhante ao do europeu do que os demais membros dos outros grupos. (SHELLEY; WATSON, 1936, p.710).

Qual contexto repousa por de trás das teorias de Shelley e Watson? O valor dúbio dos métodos e das análises empregados por esses dois médicos é facilmente notável ao passo que se entra em contato com suas conclusões. Ao se correlacionar as ideias desses dois médicos comissionados pelo governo da Niassalândia com as condições político-sociais desse protetorado inglês na África Central é possível encontrar muitas ressonâncias familiares à administração colonial dos anos de 1930. ${ }^{10}$

Niassalândia era parte de um grupo de colônias britânicas nas quais os europeus eram considerados os principais atores na exploração dos recursos. Os africanos, por sua vez, eram seus subalternos nesse processo. Nos anos que precederam a Depressão (1929), essa exploração se intensificou através do sistema thangata, no qual o locatário de uma parcela pertencente às terras de europeus deveria trabalhar um mês na propriedade do arrendatário, sem salário, para pagar o imposto e outro para saldar o aluguel da terra. Tal prática era justificável pela lei colonial de 1912 que argumentava pelo caráter não-confiável dos membros nativos de povos como os Yao e os Mang'anja. Essa retórica serviu de justificativa para outras determinações que claramente desenhavam diferenças entre os direitos dos colonos europeus e daqueles nativos. Contudo, a discriminação do sistema colonial em Niassalândia se tornou mais evidente através da atuação John Chilembwe. (PHIRI, 1976, p. 85-92).

Chilembwe denunciou os mais diferentes tipos de injustiças praticadas nas colônias e foi o porta-voz de muitos nativos ao descrever em seus discursos a rotina de insultos, discriminação e violência praticada pela administração colonial contra os nativos africanos. Com a explosão da Primeira Guerra, em agosto de 1914, escreveu para o jornal de colonos europeus o Nyasaland Times, protestando contra o uso de africanos em uma guerra de "brancos". Sua carta não se resumia em uma crítica a o recrutamento de nativos, mas incluía um desafio à administração colonial:

Em tempos de paz tudo [é] somente para os europeus, e ao invés de honra somos contemplados com sofrimento e humilhação. A verdade é que não temos voz nesse Governo [...]. Mas em tempos de guerra tem se acreditado que somos necessários para dividir suas dificuldades e

${ }^{10}$ Sobre a história política de Niassalândia: (POWER, 2010; PHIRI, 1976; HABTE; WAGA. 2010). 
derramar nosso sangue com igualdade. Mas considerando essa guerra de dimensão mundial, nós compreendemos que esta não é uma guerra real, ou uma guerra governamental, nem uma guerra que possa ser definida em qualquer outra descrição já conhecida; esta é uma guerra de nações livres contra um sistema demoníaco de dominação imperial e de exploração nacional [...] Seja qual for a razão pela qual fomos convidados a nos juntar a essa guerra, fomos convidados a morrer por Niassalândia. Vamos deixar as a considerações nas mãos do Governo, e acreditamos na misericórdia do todo poderoso Deus que as coisas irão melhorar e que o governo reconhecerá nossa indispensabilidade, e que a justiça prevalecerá. (POWER, 2010, p. 18)

A crítica de Chilembwe à segregação e às falhas do sistema colonial paternalista foi suprimida pela censura do governo colonial. Poucos meses após a não-publicação de sua carta, John Chilembwe liderou uma rebelião armada contra a administração colonial estrangeira. O relatório produzido pela comissão de inquérito formada por europeus que viviam em Niassalândia e que estavam interessados em encontrar as verdadeiras causas que motivaram a revolta é especialmente relevante para os objetivos desta pesquisa. Ao tomar-se como exemplo a posição do governador Smith sobre as causas da rebelião, ele afirmou:

[...] quanto mais interesses adquiridos por africanos na propriedade individual da terra e no comércio e na indústria, maiores são as possibilidades de se reprimir os instintos predatórios e os evidentes atos rebeldes [...] deveria haver uma gradual e também extensiva participação dos nativos mais ilustres, progressistas e educados em sua própria administração. [...] (POWER, 2010, p. 20)

No exposto acima, o Governador sugeriu que a extensão da propriedade de terra e o envolvimento no comércio por parte dos africanos poderia minimizar os atos rebeldes e permitir que os nativos reprimissem seus instintos predatórios, como também recomendou uma maior participação de nativos "civilizados" na formação de um autogoverno. O discurso do Governador Smith é significativo para esse estudo, pois aponta importantes traços da mentalidade dos europeus colonizadores, especialmente no que tange às diversas formas que a mente dos colonos europeus representava os sujeitos africanos, e de como a esfera política se apoderou dessa imagem a fim de favorecer suas manobras. 
Ao mesmo tempo em que a citação do Governador reforça a hipótese de que o sistema do governo indireto se tratou de uma resposta aos rebeldes que exigiam maior participação política e igualdade social, ela também reafirma um certo "primitivismo" dos africanos quando destaca a necessidade de que seus instintos fossem reprimidos e quando ressalta a importância de educação formal como requisito dos futuros governantes africanos.

Apesar de ter falhado em traduzir em termos práticos seu lema "África para os africanos"11, a insurreição promovida por Chilembwe demonstrou a fragilidade do governo colonial, a vulnerabilidade dos colonizadores europeus e a necessidade crítica de implantar representantes de nativos africanos no governo colonial. As críticas e a revolta de Chilembwe foram determinantes para a implementação do governo indireto e assinalaram uma tácita rejeição dos povos africanos ao discurso da "missão civilizatória" por meio da educação ocidental.12

É nesse contexto que se torna necessária a leitura do relatório de Shelley e Watson e muitos outros escritos sobre a mente dos africanos no período entre guerras. Nesse relatório, as análises médicas expressam, em uma poderosa linguagem científica, muitos dos medos sentidos pelos administradores coloniais. Baseados na evidência de que a maioria dos pacientes esquizofrênicos que estiveram envolvidos em certos crimes marcados por violência física sofria de ilusões do tipo europeu, isto é, carregadas com o ideal de poder, controle e riqueza; Shelley e Watson (1936, p. 729) argumentaram que o homem "primitivo" se definia pela virtude biológica de responder a qualquer tipo de situação perigosa por meio do mecanismo de luta corporal, e a existência desse mecanismo explicaria a alta incidência de homicídios entre os nativos esquizofrênicos: "não se pode esperar que o nativo possa exercer completo controle sobre seus poderosos instintos depois de um período comparativamente curto de contato com a civilização.".

O exercício que se flagra esses dois médicos desempenharem é a preocupação em definir os padrões de comportamento dos africanos em seu estado "normal". Shelley e Watson descreveram um tipo de distúrbio mental não correspondente aos padrões europeus, que era resultado de um conjunto de condições muito particular ao indivíduo africano, nativo, negro e educado nos moldes ocidentais. Ao que pa rece, esses pesquisadores não demonstraram preocupação ao atestarem ausência de compatibilidade com as

\footnotetext{
11 O slogan "África para os africanos" é representativo do movimento Pan-Africanista. John Chilembwe foi cozinheiro da família do missionário batista Joseph Booth e como consequência acabou batizado na Igreja Batista.Chilembwe acompanhou Booth para os Estados Unidos como assistente. Na América do Norte, Chilembwe frequentou o Virginia Theological College, onde entrou em contato comos ideais do movimento Pan-Africanista. $O$ pan-africanismo foi relativamente popular entre as elites africanas e os setores so ciais nativos e educados ao longo das lutas pela independência da segunda metade do século XX. Quando Chilembwe retornou a Niassalândia, ele foi ordenado pastor batista pela National American Baptist Convention, inspirado pelos ideais do movimento, ele desenvolveu um projeto junto das populações africanas na zona rural a fim de melhor a qualidade de vida dos mesmos e logo encontrou a oposição dos latifundiários europeus que o acusaram de fomentar o nacionalismo. Sobre o movimento Pan-Africanista ver Decraene (1962) e Harris e Zeghidour (2010).

${ }^{12}$ Nos estudos historiográficos sobre Chilembwe, autores como Power, J. e Phiri, D. D. defendem o papel de Chilembwe como um líder nacionalista pioneiro na luta pela independência da Niassalândia.
} 
categorias patológicas europeias. De acordo com McCulloch (1995, p. 114), etnopsiquiatras como Shelley e Watson, aceitavam o modelo evolucionista que permitia traçar diferenças significantes entre os europeus "avançados" e povos não-europeus "primitivos". Assim, em se tratando da comunidade de Niassalândia, os médicos pouco se importaram se as variações existentes em relação aos padrões esperados pudessem comprometer a veracidade de suas análises..

De forma a avaliar a relevância mais geral dessas afirmações, Megan Vaughan (1991, p. 109) afirmou que "[...] as produções da psicologia e da psiquiatria, juntamente com os discursos antropológicos, realmente ajudaram a definir ou até mesmo "inventar" o sujeito africano para a audiência europeia." Os primeiros trabalhos produzidos por psiquiatras na África Ocidental eram determinados por valores raciais. Eles argumentavam cientificamente em favor da existência de conexões entre a estrutura orgânica do cérebro dos africanos com a psicologia dos mesmos e mais diretamente com as psicopatologias desenvolvidas por esses povos "primitivos". Dr. H. L. Gordon, superintendente do Hospício de Mathari em Nairóbi durante os anos 1930, trabalhou juntamente com F. W. Vint, bacteriologista contratado pelo governo colonial, com a finalidade de prover provas científicas em favor do argumento sobre a inferioridade racial dos africanos. (GORDON, 1935-1936).

Durante o período em que Gordon trabalhou no Mathari ele desenvolveu um estudo junto aos internos do hospício notando a frequência de certos tipos de desordens incomum aos padrões recorrentes entre europeus. $O$ médico alienista também havia notado o aumento da incidência de doenças mentais entre os adolescentes africanos. Para Gordon a chave para explicar tal fato repousava na personalidade dos africanos. De acordo com Gordon, quando diante de circunstâncias comuns ao cotidiano da vida na comunidade nativa, somente aqueles africanos com limitações na parte frontal do cérebro sofreriam de doenças mentais. Contudo, quando expostos ao cenário colonial, um alto número de adolescentes estava adoecendo. Gordon acreditava que a razão era óbvia:

As evidências atuais são contrárias aos nossos nativos estarem bem equipados com a parte frontal do cérebro tanto quanto está a média dos europeus. Sob um ambiente tradicional o desenvolvimento de síndromes pode acontecer em números menores. Diante do estresse e das dificuldades do ambiente estranho que estamos introduzindo quem irá dizer que essas síndromes não podem se tornar muitas? O sujeito nativo resultante desse estresse e dessas dificuldades pode ser encontrado dentro daquilo que vagamente chamamos de impacto da civilização. (GORDON, 1935-1936, p. 333). 
Gordon estava particularmente preocupado com o efeito que as escolas europeias estavam gerando sobre as mentes subdesenvolvidas dos jovens africanos. A partir de seu breve estudo com dezenove adolescentes do Mathari, todos educados, ele concluiu que a exposição ao modelo educacional ocidental era a razão para suas doenças. $O$ sistema educacional oferecia muitas dificuldades para esses jovens que, devido a sua estrutura cerebral, eram incapazes de assimilar as complexas formas de conhecimento ensina das. Gordon não estava certo quanto à conduta a ser seguida pela polícia colonial, mas estava confiante que a ciência iria eventualmente providenciar uma resposta. (GORDON, 1935-1936, p.335).

Gordon havia encorajado F. W. Vint, médico bacteriologista do Laboratório de Pesquisas Patológicas de Nairobi, a desenvolver uma pesquisa sobre a capacidade craniana dos africanos usando material recolhido durante autópsias realizadas nos hospitais de Nairobi. A convite de Gordon, Vint apresentou suas conclusões à Associação Médica Britânica em Nairobi. Apesar de reconhecer os limites de uma pesquisa sobre inteligência conduzida em cadáveres, Vinti concluiu, a partir da pesagem dos cérebros e da avaliação das dimensões do córtex frontal, que "o último estágio de desenvolvimento atingido pela média dos nativos africanos é a mesma atingida por garotos europeus entre 7 e 8 anos de idade". (VINT, 19321933, p. 30-31).

O "vigor científico" da teoria de Vint teve grande apelo entre a comunidade médica, a julgar, principalmente, pelo grande número de publicações debatendo as conclusões alcançadas por Vint (GORDON, 1934). Gordon parabenizou o patologista por ter confirmado os resultados de sua própria pesquisa sobre a inteligência do africano realizada ao longo de seu trabalho no hospital Mathari. Um segundo alienista, denominado Anderson, compartilhou que em seus 32 anos vivendo na África não havia encontrado um único africano que tivesse desenvolvido capacidades intelectuais como as de um europeu normal. Os dois médicos estavam impressionados com os resultados apresentados por Vint, e ambos expressaram certa preocupação em relação ao perigo em que os africanos estavam expostos ao viverem em um ambiente inadequado para sua capacidade intelectual. (GORDON, 1934, p. 39-42).

A visão de Gordon sobre os processos sociais e seus reflexos na mente dos nativos não eram necessariamente típicos das conclusões de alienistas do período colonial. Todavia, assim como Gordon, Vint, Anderson, Shelley e Watson compartilhavam da ideia de que a exposição dos africanos nativos ao mundo civilizado construído pelos colonos poderia ser nocivo para a saúde mental dos primeiros.

Foi durante os anos 1930 que os reflexos políticos da educação ocidental oferecida a os nativos foram sentidos pela administração colonial. Reagindo vigorosamente à agressão da Itália contra a Etiópia (1935-1941) e à ascensão do fascismo na Europa, intelectuais africanos conduziram um aprofundamento da doutrina pan-africanista e uma ampliação de suas 
atividades tanto na África como na esfera mundial. Para A. Habte e T. Wagaw, os colonizadores revelaram-se iludidos no tocante ao grau de alienação dessa elite instruída entre os africanos. Particularmente, sua educação ocidentalizada permitiu que muitos transcendessem as barreias étnicas entre grupos linguísticos e enveredassem em movimentos nacionalistas pró-independência, transformando-se em porta-vozes do conjunto de povos dos territórios coloniais, independentemente de idiomas ou etnias (HABTE; WAGAW, 2010, p. 820).

O renascer de movimentos contestatórios, que no momento teciam um discurso nacionalista, não somente alertou a administração colonial para o perigo de movimentos locais pela independência, como também chamavam pelo apoio de outras comunidades negras no cenário internacional.

A agressão contra a Etiópia colocou em espetacular evidência a dependência da África em relação à Europa, assim como a hesitação das grandes potências que isoladas ou sob a égide da Sociedade das Nações, não atuaram efetivamente, no sentido de tornar respeitáveis a liberdade e a justiça. Desta forma, uma série de associações, conferências e manifestações foram organizadas a fim de ganharem o apoio da opinião pública não somente em favor da causa da Etiópia, mas de forma geral, em favor de todos os africanos submetidos à administração de países europeus. Iniciativas como a do guianês Ras Mankonnen, que havia estudado nos Estados Unidos e exercia grande influência sobre os movimentos negros na Inglaterra, que juntamente com os quenianos Peter Milliard e Jomo Kenyatta, criaram a PanAfrican Publishing Company, responsável pela publicação mensal do Pan-Africa, representam o cenário de mudanças pelo qual passava a vida colonial. (HARRIS, 2010. p. 852-854).

Os estudos e relatórios produzidos por médicos europeus sobre a saúde mental dos nativos africanos produzidos e publicados nos anos do entreguerras parecem dialogar diretamente com esse contexto sócio-político. Ao passo em que definem os limites intelectuais africanos e a sua exposição ao modelo educacional europeu como causas imediatas de um tipo de distúrbio muito próprio do indivíduo africano, também representam a visão da elite colonial sobre os líderes nacionalistas e seu manifesto. Gordon, no editorial da revista South African Medical Journal, de forte viés eugenista, ao comentar o seu trabalho e de Vint, concluiu:

[...] que os melhores nativos eram biologicamente inferiores à média europeia [...]" e que esse fato poderia trazer consequências "[...] para toda a política colonial, principalmente no que compete aos nativos sob o controle e administração europeia [...] (GORDON, 1934. p. 2). 
Nota-se, nesses relatórios, o esforço empregado por esses médicos em estabelecer as diferenças existentes entre europeus e africanos em seu estado psicológico de normalidade. Neste exercício, verifica-se a construção de um estereotipo africano, a formação de uma imagem racista e etnocêntrica sobre o indivíduo nativo. Compreende-se, da mesma forma, que as conclusões contidas nessas pesquisas foram moldadas por uma ideologia colonial, e que por meio do discurso médico-científico ofereciam respostas aos movimentos nacionalistas emergentes ao mesmo tempo reforçavam a presença dos colonizadores e legitimavam as políticas colonialistas.

\section{Os Psicanalistas}

Embora seja incorreto afirmar que psiquiatras e psicólogos coloniais formaram um grupo homogêneo, a maior parte deles se debruçou sobre a questão de quem era realmente o sujeito africano. Nessa discussão, a maioria se deteve a um discurso sobre a diferença. Os fundamentos dessa diferença foram primeiro desenhados por meio de estudos físicobiológicos nos anos 1930, embora na década de 1950 tenham ganhado contornos socioantropológicos.

Sander Gilman (1985, p. 102) afirmou em seu Difference and Pathology que estereótipos são representações cruas do mundo, cuja função seria perpetuar um sentido artificial de diferença entre um e outro e preservar a ilusão de controle. Como será visto, uma série de categorias freudianas "universalistas" serão manipuladas por etnopsiquiatras, afim de reforçar as diferenças entre europeus e africanos. Além disso, as próprias comparações de Freud entre primitivos e esquizofrênicos se apresentaram como um verdadeiro convite direto para a construção de estereótipos do primeiro grupo que claramente ressaltavam seu primitivismo, bem como a sua "necessidade" de subordinação.

Freud usou o termo "primitivo" de numerosas maneiras, entretanto, a forma mais comum era para designar um tipo particular de entidade psíquica. Seus "selvagens" eram homens e mulheres em quem os processos primários (a forte presença do id) eram mais marcantes do que nos europeus. Por conta da ausência de um superego bem desenvolvido, sanções externas restringindo impulsos sexuais eram essenciais nas sociedades selvagens (FREUD, 1946, p. 3). Em Totem e Taboo, Freud argumentou sobre como a falta de objetividade no pensamento "primitivo" constituía um importante link entre primitivos e neuróticos. Segundo Freud, o modo de pensar do primitivo era, 
[...] altamente sexualizado e [...] isso contribui para uma crença na onipotência do pensamento, uma confiança inabalável na capacidade de dominar o mundo e uma ausência de acessibilidade e objetividade dos fatos a qual poderia iluminar a compreender seu verdadeiro lugar no mundo (FREUD, 1946, p. 116-117).

A perspectiva freudiana sobre a psicologia primitiva teve seus efeitos sobre o trabalho dos etnopsiquiatras na África colonial. B. J. F. Laubscher, por muitos anos encarregado do cargo de médico alienista do hospício de Queenstown, apresentou forte interesse pela psicologia freudiana e abordou a questão do papel da sexualidade entre os africanos na formação do caráter e no desenvolvimento de doenças mentais entre os nativos. Em contraste com os neuropsiquiatras, Laubscher (1937) enfatizava a influência da cultura, das práticas sociais, das crenças e dos costumes como elementos determinantes na constituição de patologias mentais na sociedade nativa.

Laubscher estava especificamente interessado nos costumes sexuais do povo Tembu na Rodésia do Sul. Apesar de não aplicar métodos eugenistas, suas conclusões foram equivalentes àquelas apresentadas por Gordon e Vint no Quênia: os africanos em seu estado normal apresentavam um número significativo de características correspondentes à de um europeu psicótico. Entretanto, para Laubscher, mais do que a raça, a cultura africana era a causa primeira na formação de hábitos patológicos entre os africanos.

Notando que a maioria dos pacientes masculinos do asilo de Queenstown na África do Sul que apresentavam esquizofrenia e epilepsia não eram circuncisados, o médico deduziu que a esquizofrenia era resultado de uma possível marginalização desses pacientes dentro da sua própria comunidade. Na opinião de Laubscher, os esquizofrênicos provavelmente apresentavam uma relação patológica com a mãe, a qual, por sua vez, teria os desencorajado a se submeter ao ritual. O alienista defendeu que os africanos que geralmente cometiam estupro não eram circuncisados, de maneira a comprovar suas afirmações. Foram por ele mencionados alguns casos de internos que se enquadravam nesse padrão. Com base na noção freudiana de neurose enquanto uma patologia resultante da atividade sexual, Laubscher sugeriu que os africanos, quando desprovidos das condições heterossexuais "normais", eram compelidos a buscar alternativas. (LAUBSCHER, 1937, p. 270).

O interesse de Laubscher no comportamento sexual dos africanos havia sido inspirado, como ele mesmo relatou, por um número de ataques sádicos cometidos por homens africanos sobre mulheres europeias. Ele deduziu que esse tipo de crime era restrito ao homem africano. Esses ataques, ou "Black Peril" como eram conhecidos, eram de fato raros, todavia, eles haviam inspirado um conjunto de legislações na Cidade do Cabo, Natal e Transvaal. As leis sobre imoralidade na África do Sul e na Rodésia do Sul se configuravam 
como um aparato legislativo e cultural designado para prever a miscigenação racial e garantir que as fronteiras raciais permanecessem invioladas. ${ }^{13}$

Essa noção de uma hipersexualidade africana era destilada entre a comunidade colonial europeia por meio da lenda do "Black Peril". Laubscher (1937) em seu trabalho, Sex, Custom and Psychopathology epitomizou o dilema enfrentado pelos colonizadores europeus na África: Eles precisavam dos negros próximos a eles para prover sua mão-de-obra, ao mesmo tempo em que temiam sua conduta. A resposta de Laubscher para esse dilema foi definir a personalidade dos africanos como patológica mesmo em seu estado normal.

O estudo de Laubscher reforçou a velha concepção do século XIX de que o ambiente urbano era nocivo para a saúde mental dos nativos. Para ele, enquanto os africanos não cometiam estupros nas reservas, nas cidades, onde eles estavam desprovidos da companhia feminina, tornavam-se uma verdadeira ameaça sexual. A estereotipação da sexualidade do sujeito masculino-africano associada à noção de que a cultura africana se encontrava em um estágio de subdesenvolvimento se comparada à civilização europeia ofereceu uma poderosa justificativa de cunho científico, tanto para as leis coloniais antimiscigenação, como para a política da segregação espacial entre europeus e africanos em solo colonial.

Laubscher vem a somar a esse grupo de médicos alienistas europeus que atuaram nas colônias britânicas na África que, independentemente de suas metodologias ou dos diferentes territórios em que atuaram, comungavam da perspectiva da aculturação. As grandes transformações produzidas pela urbanização sobre as costumes e hábitos nativos havia se tornado tema recorrente nas pesquisas psiquiátricas e, ao passo em que os movimentos nacionalistas intensificavam suas ações e desafiavam a administração colonial, o trabalho desses bacharéis passou a ser mais requisitado. Dessa forma, refletem em grande medida as preocupações das elites coloniais durante essas duas décadas.

Se fosse possível falar de uma "escola" psiquiátrica do leste africano, sem sombra de dúvida o nome de J. C. Carothers surgiria como um de seus principais expoentes. Carothers nasceu em solo africano, mas se graduou médico na Universidade de Londres. Após alguns anos exercendo a medicina nas mais diferentes regiões do Quênia foi nomeado superintendente do hospício Mathari sem possuir qualquer qualificação nessa área ${ }^{14}$. Mesmo após sua formação em psiquiatria e psicologia em Londres em 1946, Carothers publicou muito pouco. Até sua aposentadoria, o que se pode encontrar publicado por ele

\footnotetext{
${ }^{13}$ Muitas pesquisas historiográficas se debruçam atualmente sobre a relação entre poder colonial e sexualidade. $O$ conjunto de normativas legais estabelecidas pela administração colonial em relação ao comportamento sexual tanto dos colonos europeus quanto dos africanos, especialmente na região sul das colônias britânicas, são compreendidas não somente como uma forma particular de controle social, mas também como uma maneira de reforçar o mito do primitivismo africano. Para um maior aprofundamento da temática ver: (JACKSON, 2011. p. 7394; PAPE, 1990. p. 31-49; MCCULLOCH, 2000).

${ }^{14}$ As informações sobre a vida pessoal de Carothers foram retiradas de uma série de entrevistas feitas por Jock McCulloch na casa de Carothers na cidade de Havant na Inglaterra em novembro de 1986. Essas entrevistas hoje podem ser acessadas no arquivo de áudios da África colonial da Biblioteca Britânica em Londres.
} 
eram apenas alguns poucos artigos ou relatórios comissionados pelos governos da Rodésia do Sul e Uganda em 1948 e 1949, respectivamente, sobre os serviços de saúde mental desses territórios.

A primeira publicação foi no East African Medical Journal e tratou-se de uma review sobre os internos do Mathari e algumas reflexões sobre as características distintivas das doenças mentais dos africanos. As conexões que Carothers estabeleceu nesse relatório entre insanidade e o contato dos povos africanos com os europeus eram, na verdade, bastante convencionais: baseado nos padrões freudianos, o médico via uma série de paralelos entre personalidade dos africanos com a de um europeu branco esquizofrênico. $O$ que foi realmente distintivo em suas futuras análises foi sua teoria sobre a relação entre a cultura africana e a personalidade do sujeito africanos: Os africanos tinham a tendência de projetar suas emoções e sentimentos no mundo real, ao invés de examiná-lo com lentes objetivas (CAROTHERS, 1940, p. 95-100).

O médico ainda defendeu que a família africana era designada a prover certo senso de segurança aos seus membros. Contudo, quando expostos às leis prescritas por grupos sociais externos, os africanos, em especial os adolescentes se sentiam deslocados, na maioria das vezes, perdidos. Carothers acreditava que em uma sociedade tradicional alguns africanos poderiam apresentar insanidade, contudo, aqueles que haviam se tornado psicóticos durante o neocolonialismo, eram vítimas do contato com uma cultura mais avançada. Para Catothers, "o africano normal não é esquizofrênico, mas o passo de uma atitude primitiva para uma esquizofrenia, era muito curto e muito fácil" (CAROTHERS, 1940, p. 99).

A relação entre cultura e doenças mentais foi amplamente explorada por Carothers em seu artigo publicado em 1948 no periódico internacional Journal of Mental Science. No interior das comunidades nativas, ele explicou, existiam fortes laços de igualdade e conformidade, onde os sucessos individuais, a inovação ou a originalidade não possuíam espaço e muito menos status. Ao contrastar africanos e europeus, Carothers defendeu a tendência dos últimos de se comportarem de acordo com a regra geral e sentindo-se responsáveis pelo seu próprio grau de conformismo. Diferentemente dos africanos, Carothers destacou que a força da personalidade europeia derivava do indivíduo separado do coletivo. (CAROTHERS, 1947, p. 548-554).

O jovem Carothers ainda se preocupou em conceituar um tipo de desordem mental muito decorrente entre os pacientes do Mathari, cujas características não se enquadravam em nenhum tipo de nosologia estabelecida em manuais psiquiátricos europeus. "Frenzied anxiety" foi o termo usado por ele para definir essa disfunção mental marcada por um alto nível de ansiedade difundida na mente dos nativos que impeliria os indivíduos a agir violentamente. Carothers explicou que enquanto europeus sofriam de depressão em decorrência da culpa, os africanos se voltavam à violência contra o mundo externo: "Provavelmente, as condições que permitem rotular a tendência africana à frenzied anxiety 
substituam nos nativos muitos dos tipos de neuroses e até mesmo as depressões detectadas entre os europeus" (CAROTHERS, 1947, p. 71). O ensaio de Carothers se configura como uma clara advertência à comunidade branca europeia colonial, principalmente porque esclarece que os africanos mais propícios a apresentarem esse distúrbio viviam nos centros urbanos e eram empregados pelas elites coloniais.

Apesar de Carothers ter atribuído a influência da cultura como causa maior nas diferenças nas doenças mentais entre europeus e africanos, ele era familiar às teorias de Gordon e Vint e, quando em sua especialização em psiquiatria em Londres no período pósguerra, o etnopsiquiatra também se concentrou na estrutura cerebral dos nativos e publicou Frontal Lobe Function and the African. Carothers utilizou os dados coletados por seus colegas para construir sua teoria da "lobotomia natural". Em seu artigo ele argumentou que:

[...] a semelhança entre um paciente europeu lobotomizado com um africano primitivo é, em muitas formas, completa: $O$ africano, com sua total ausência de síntese, necessita utilizar os lóbulos frontais de forma mínima (devido aos limites de funcionamento dos mesmos), e todas as peculiaridades da psiquiatria africana podem ser definidas pela instintividade frontal. (CAROTHERS, 1951, p. 71)

Ao longo de quase uma década o trabalho de Carothers foi amplamente lido e bem recebido pelo círculo de psiquiatras coloniais. Apesar de alguns se oporem às suas ideias ${ }^{15}, 0$ etnopsiquiatra não encontrou dificuldades em ganhar acesso aos melhores periódicos acadêmicos tanto na África colonial como na Europa. Enquanto Frantz Fanon tinha que se contentar em publicar os resultados de suas análises dos efeitos negativos da colonização sobre a personalidade dos africanos em fóruns obscuros ${ }^{16}$, Carothers, por sua vez, representava a mainstream da ciência etnopsiquiátrica. Significativamente, sua proeminência coincidiu com a ascensão dos movimentos nacionalistas africanos no período pós-guerra.

Quando já aposentado, Carothers foi comissionado pela Organização Mundial de Saúde em 1952 para escrever uma monografia sobre a saúde mental na África, a qual não foi somente responsável por aumentar sua reputação junto à comunidade médica colonial, mas

\footnotetext{
15 Em 1958, por exemplo, Jack Simons publicou um artigo atacando Carothers e seus colegas etnopsiquiatras. Simons afirmou que Carothers nunca havia explorado inteiramente a antropometria para provar a inferiodade dos africanos (SIMONS, 1985, p. 379-81).

${ }^{16} \mathrm{Em} 1952$, quando Carothers publicava sua teoria sobre o lóbulo frontal do indivíduo africano, Fanon publicava suas críticas a colonização e seus efeitos negativos para a saúde mental dos nativos em um periódico do Magreb africano L'esprit e somente uma década mais tarde seu trabalho ganharia o mundo anglofônico.
} 
disseminar estereótipos sobre o indivíduo africano. Em The African Mind in Health and Disease (CAROTHERS, 1953), a questão chave abordada era se a mentalidade dos africanos era fundamentalmente diferente daquela dos europeus e como essa diferença poderia ser explicada. Na primeira parte, o etnopsiquiatra confiou mais uma vez em Gordon e Vint para demonstrar a inferioridade do cérebro do negro em comparação ao caucasiano (CAROTHERS, 1953, p. 77). Entretanto, grande parte de seu trabalho estava dedicado às correspondências entre os fatores neurológicos, o temperamento e a cultura dos africanos.

Carothers dedicou um capítulo inteiro de sua pesquisa ao desenvolvimento intelectual e emocional dos nativos. Ele citou largamente o trabalho de outro etnopsiquiatra freudiano, J. F. Ritchie e seu The African as Suckling and as Adult. (RITCHIE, 1968). Ritchie, chefe do principal hospício da Rodésia do Norte nos anos 1940, declarou em um artigo publicado pela primeira vez em 1943, pelo Instituto Rhodes-Livingstone, que não havia encontrado nenhuma diferença essencial entre a mente dos africanos e dos europeus, contudo, procurou descrever como os cuidados na infância combinados à prática excessiva de sexo na adolescência criavam uma condição que limitava o equilíbrio emocional dos africanos (RITCHIE, 1968, p. 37-49). Ritchie havia contrastado as formas tradicionais africanas de educar e criar uma criança com aquelas praticadas pelos europeus na década de 1940.

Apesar de partirem de diferentes premissas, Ritchie apresentou conclusões que ofereceram os fundamentos teóricos necessários para as conclusões do trabalho de Carothers. Em suas análises, Carothers enfatizou as inconsistências nas atitudes dos pais e a pobreza social como características fundamentais da cultura africana. Ele declarou que não havia uma condição segura para o desenvolvimento da mente da criança africana e que, ao contrário, sua mente era governada por interconexões entre regras e tabus, cuja origem era pré-histórica. Essas regras serviam para integrar membros à comunidade, mas também para estancar seu desenvolvimento individual. A integração entre os africanos era, segundo o etnopsiquiatra, social ao invés de cerebral, e o indivíduo era integrado na sociedade, mas nunca em si mesmo. Carothers, inclusive, citou o trabalho do psicólogo suíço Jean Piaget, especialista em teorias cognitivas, para concluir que o desenvolvimento completo do intelecto requeria certas formas de experiência com os cuidados infantis que não estavam disponíveis para os africanos. (CAROTHERS, 1953, p. 102).

Enquanto Carothers reconheceu o importante papel de doenças tropicais e da desnutrição na formação da personalidade do indivíduo africano adulto, também descreveu o temperamento dos mesmos:

O africano tem sido descrito como convencional, altamente dependente do estímulo físico e emocional, falta de espontaneidade, tenacidade, julgamento e humildade, inapto para a abstração sonora e para a lógica, 
dado a fantasia e a criação, em geral, instável, impulsivo, não-confiável, irresponsável e vivem no presente sem refletirem ou terem qualquer ambição em relação as pessoas que não fazem parte de seu círculo. (CAROTHERS, 1953, p. 57).

The African Mind representou a destilação de mais de dez anos de pesquisa e vinte anos de prática de clínica e, nele, Carothers fez uma das apresentações mais sucintas da teoria da inferioridade africana. A chave de sua teoria foram as conclusões apresentadas por Vint e Ritchie, sendo suas referências estabelecidas em dois âmbitos: raça e cultura. The African Mind representou as profundas crenças dos colonos europeus de que os africanos eram intelectualmente e culturalmente inferiores. Como para Carothers a ciência precisava ser altamente compreensível, tratou de expandir sua explicação das "deficiências" do sujeito africano considerado normal e procurou apontar para seus reflexos na cultura, na raça, na morfologia cerebral, na moralidade e no nível intelectual. Vista dessa forma, McCulloch destaca que The African Mind não significou para a história da África um estudo sobre a saúde mental, mas um estudo político, uma teoria sobre as falhas do comportamento nativo nos aspectos morais, econômicos e civis (MCCULLOCH, 1995, p. 62).

A indicação de Carothers, em 1954, como o único homem a produzir um estudo sobre a rebelião Mau Mau, o inseriu diretamente no mundo da política. Em outubro de 1952, estado de emergência havia sido declarado no Quênia. Ao longo dos seis anos totais de embate, trinta e dois colonos europeus foram assassinados e mais sessenta e três membros das forças de segurança. Os soldados britânicos e a polícia queniana mataram mais de onze mil membros do movimento Mau Mau.

A historiografia sobre o movimento Mau Mau tem passado por grandes mudanças, principalmente no que compete as formas como o movimento foi compreendido ${ }^{17}$. Essa rebelião ficou praticamente restrita à um único povo, os Kikuyu, que reclama vam o direito de posse sobre um território do Quênia conhecido como White Highlands. Os Kikuyu argumentavam que essa terra havia sido apropriada ilegalmente pelos colonos europeus e, em 1920, a Kikuyu Association iniciou uma batalha jurídica para reivindicar a posse do território. Somente em 1933, a Comissão formada pelo governo colonial para investigar a questão, ofereceu uma resposta, que não foi favorável ao povo Kikuyu. A resistência Kikuyu foi contida por quase dez anos, entretanto, a Depressão de 1929 e o grande número de soldados africanos arrastados para o exército britânico para lutar na Segunda Guerra inflaram os ânimos dos militantes quenianos na luta por seu território. Em 1944 foi fundado a Kenya African Union (KAU), a qual, sob a liderança de Jomo Kenyatta, deu origem ao Mau Mau.

${ }^{17}$ Para os mais recentes estudos na rebelião nacionalista do Quênia, ver o expressivo trabalho de Ogot (1972). Para um estudo sobre a violência britânica durante a rebelião ver Edgerton (1989). 
Uma breve análise da historiografia contemporânea ao movimento Mau Mau pode iluminar o caminho da presente análise na direção de melhor compreender a mentalidade das elites coloniais europeias e, mais especificamente, refletir como o movimento Mau Mau foi interpretado pelas mesmas. Em 1954, por exemplo, John Wilkinson, médico britânico que trabalhava no distrito de Nyeri no sul do Quênia, relatou que o objetivo da rebelião Mau Mau era unificar todos os negros quenianos sob sua liderança e acabar com as imigrações de negros para as colônias brancas. Para Wilkinson, o movimento era caracterizado por uma ideologia anticristã, inspirado por um ódio contra os europeus, marcado pelo uso da violência e do terror e buscava impor formas totalitárias de governo. Wilkinson reconheceu o movimento como patológico e acreditava ser inútil qualquer tipo de negociação entre o KAU e o governo colonial britânico. (WILKINSON, 1954, p. 194-314). Em 1957, Michael Kirby, que como Wilkinson era um médico europeu, publicou sua própria interpretação do movimento Mau Mau. Kirby dividiu a vida de um kikuyu em três fases e examinou os estresses e conflitos de cada uma delas e seus reflexos na vida dessa geração de jovens rebeldes. Para Kirby (1957, p. 529-32), os Kikuyu eram agressivos, pois haviam experimentado um conflito de realidades por meio de uma educação mista entre as formas tradicionais e europeias, que mais tarde viria a encorajá-los a tomar parte no movimento Mau Mau.

Os estudos contemporâneos ao movimento Mau Mau estavam claramente fundamentados na ideia do "choque cultural" entre os Kikuyu e os colonos europeus. De fato, o povo Kikuyu estava particularmente afetado pelas mudanças resultantes desse contato, não somente porque dentro dos novos moldes econômicos constituíam a força de trabalho explorada, mas também, pelo fato dessas mudanças terem contribuído na formação de uma classe educada aos moldes ocidentais, a qual compunha grande parte da liderança do movimento.

Dadas as circunstâncias, é relevante pensar as causas que, curiosamente, levaram o governo britânico a buscar uma explicação da rebelião junto a um psiquiatra, ao invés de urgir pelo trabalho de um antropólogo ou historiador. Em um debate sobre a igualdade racial no Parlamento Federal em Salisbury no ano de 1954, o Primeiro Ministro Huggins recomendou que todos deveriam ler o trabalho de Carothers, já que nele "eles irão encontrar uma descrição de praticamente cada raça existente no mundo que emergem de um estado pré-aculturação" (VAUGHAN, 1991, p. 114) ${ }^{18}$. Em novembro de 1953, Carothers recebeu uma carta do então governador de Nairobi, S. R. Mortiner, que oferecia ao etnopsiquiatra uma comissão para escrever um relatório sobre as causas da rebelião Mau Mau. O governador explicou que enquanto a rebelião estava sendo suprimida, o governo do Quênia estava preocupado com suas consequências a longo prazo: "Erradicar a amargura e a suspeitas tão profundamente enraizadas (entre os kykuyu) era um problema muito mais difícil, cuja

18. O discurso de Huggins foi encontrado por Vaughan nos Debates da Assembleia Federal da Federação da Rodésia e da Niassalândia de 1955. 
solução requer toda e qualquer assistência e conselho de um especialista que nós (o governo) possamos obter" (MCCULLOCH, 1995, p. 77). Mortmer encerrou sua carta requisitando a discrição de Carothers sobre seu comissionamento: "Estamos desafiados a evitar a publicidade sobre sua visita e eu espero que você seja capaz de evitá-la no Reino Unido". (MCCULOOCH, 1995, p. 77).

The Psychology of Mau Mau ofereceu uma tentativa de compreender os problemas psicológicos dos Kikuyu. Os primeiros dois capítulos foram dedicados a psicologia dos nativos africanos e, assim como Carothers já havia demonstrado em seu The African Mind, apresentar os problemas gerados pela transição da cultura tradicional para a moderna. Os dois últimos capítulos, são especialmente relevantes, pois abordam a psicologia do movimento Mau Mau e apresentam recomendações para tratar o problema ao longo prazo.

De acordo com Carothers, os Kikuyus eram individualistas, meticulosos e litigiosos. Eram também trabalhadores esforçados que poderiam se distinguir dos demais povos, a julgar pelas grandes possibilidades de adaptação à cultura europeia. Para o psiquiatra, o futuro da colônia dependia de uma cooperação entre o governo e os membros dessa etnia. Carothers defendeu que mesmo antes da chegada dos europeus, os Kykuyu apresentavam um pequeno senso de segurança pessoal e a autoridade era mantida mais pelo medo, que pelo respeito. Quando expostos à cultura ocidental, os Kikuyu perceberam que já não possuíam mais lugar na sociedade tradicional, entretanto também não tinham alcançado o sucesso material que tanto almejavam. Vivendo em um mundo julgado malévolo, a personalidade do Kikuyu tendeu a culpar os europeus como responsáveis por todos esses desconfortos. Carothers comentou extensivamente sobre a falta de lealdade dos Kikuyu em relação ao governo britânico e também em relação aos seus empregadores:

De fato, o comportamento dos Kikuyu homens nos últimos anos tem simulado a atitude de um amante rejeitado, cujo amor havia sido desvirtuado e transformado em ódio de todos aqueles quem um dia ele amou. As tentativas (rebeldes) de reestabelecer os velhos tempos são baseadas nesse sentimento e uma vez que esta emergência for resolvida será visto quão artificial o movimento era (CAROTHERS, 1954, p. 21).

Para Carothers, os Kikuyu haviam esperado muito do governo colonial, e seu comportamento neurótico jamais poderia ser resolvido dentro do âmbito político. Armado com esse argumento, o psiquiatra recomendou que o governo queniano iniciasse um programa de construção de espaços territoriais exclusivos para os nativos africanos. As vilas, como Gordon já havia sugerido duas décadas atrás no próprio Quênia e já implantadas 
em outras colônias como na Rodésia do Sul e na África do Sul, poderiam prover uma nova sociedade para as comunidades nativas locais.

A demanda pelo conhecimento de Carothers durante o despertar do nacionalismo africano refletiu a apreensão entre aqueles que apoiavam o governo colonial sobre as possíveis mudanças políticas. O relatório de Carothers ignorou qualquer reivindicação territorial apresentada pelo movimento Mau Mau. Com a rebelião, o psiquiatra iria definir a personalidade daqueles africanos hostis ao regime colonial, como patológica, afirmando que o movimento era irracional e resultante de mentes desordenadas.

Alguns autores têm afirmado que era politicamente conivente, a contar pelo contexto, definir o movimento Mau Mau como uma rebelião irracional. A. S. Cleary, por exemplo, escreveu que os britânicos tentaram conter os danos causados pelo movimento à sua imagem pública, através da popularização da ideia de que o Mau Mau era: "uma rebelião pequena, não popular, facilmente controlável, selvagem e talvez até, um sintoma de alguma forma de psicose em massa, ou resultado da incapacidade dos Kikuyu de lidar com o mundo moderno." (CLEARY, 1990, p. 228).

Com a publicação da monografia de Carothers, a etnopsiquiatria formalmente entrava para o domínio da ação política. The Psychology of Mau Mau demonstrou como a etnopsiquiatria se mostrou eficiente em racionalizar as crenças convencionais dos colonos europeus sobre os africanos. J. Sadowsky argumentou que compreender a patologização da resistência no trabalho de Carothers, como uma manipulação cínica seria subestimar a complexidade e o poder da ideologia colonial. Para esse historiador, ambos os posicionamentos, tanto o dos rebeldes africanos como a do médico europeu (e de todos os imperialistas) apresentam um significado político dentro do contexto do neocolonialismo. (SADOWSKY, 1997, p. 105).

Para R. Keller (2001), colonizadores, imperialistas e etnopsiquiatras eram orientados por suas raízes culturais e estavam em constante diálogo com a opinião liberal. A principal preocupação de Carothers era com a emergência de um indivíduo africano individualmente maduro e saudável, tal qual era produzido pelas famílias britânicas de classe média. Ele ressaltava a importância de se seguir regras a partir de auto-regulamentação, à coerção. Carothers explicou que se os europeus se comportavam bem, isso se dava ao fato de aderirem voluntariamente aos compromissos e à responsabilidade, enquanto os africanos somente se comportavam bem por temerem as consequências de uma transgressão. As estruturas mentais eram diferentes e, somente abraçando uma e abandonando a outra é que os africanos poderiam entrar no mundo moderno (CAROTHERS, 1954, p. 25-28).

A influência universal e liberal da teoria freudiana na psicologia produzida por médicos europeus e na psicopatologia convergiam às teorias deterministas com base na raça, uma 
caracterização do indivíduo africano como coletivista, imaturo, infantil e inadequado para conviver em ambientes diferente do tradicional.

\section{Considerações Finais}

Ao se examinar os relatórios, artigos e monografias dos etnopsiquiatras apresentados neste ensaio, percebe-se que ao avaliarem seus pacientes, aplicavam conceitos e categorias de um cabedal teórico muito próprio da cultura ocidental moderna. Dentro da história europeia, a conexão entre uma conduta individual de autocontrole e a pacificação das populações, representa um processo amplamente explorado nas teorias de notáveis como Norbert Elias ${ }^{19}$ e Michel Foucault ${ }^{20}$. Apesar desse processo parecer muito próprio de um contexto europeu ou ocidental, os etnopsiquiatras africanos desconsideravam as grandes diferenças sociais do contexto africano, e persistiam em lamentar a ausência de "autocontrole" entre os africanos. Laubscher, Shelley e Watson, Gordon, Vint, Ritchie e Carothers, acreditavam que a ausência da noção de individualidade entre os africanos dificultava o desenvolvimento de um comportamento conformista às regras legais e morais.

Apesar dos muitos paralelos estabelecidos entre os europeus e africanos, com vistas a definir e confinar o insano no cenário colonial, a história da loucura na África segue caminhos muito obtusos quando comparada à história da loucura na Europa. Como Foucault sugeriu, aqueles que falhassem em se conformar as regras, tais como os insanos, as minorias étnicas, as mulheres e as classes subordinadas eram patologizados e se tornavam vítimas de ostracismo social ou de um encarceramento sistemático. No entanto, a loucura entre os africanos não deveria ser totalmente temida pelo europeu. Nas teorias etnopsiquiatras ora analisadas nota-se a preocupação em definir o caráter distintivo do sujeito africano em seu estado de normalidade. Assim, a natureza dos debates se dá em torno

\footnotetext{
${ }^{19}$ A tese central do estudo de Norbert Elias sobre os modos europeus de conduta foi baseada na conexão entre o crescimento e a extensão dos meios de violência e autocontrole em relação as "paixões" da classe dominante. De acordo com Elias, onde um forte poder centralizado emergiu, ele foi acompanhado por uma mudança de personalidade da nobreza. Para Elias, a crescente complexidade interdependência das sociedades teria aumentado os níveis de autocontrole dos indivíduos. Onde o processo era muito avançado, o autocontrole havia se tornado habitual. Desta forma, na Europa ocidental esse processo de autocontrole individual primeiro se desenvolveu entre a nobreza e depois se espalhou para os outros segmentos sociais. (ELIAS, 1978).

${ }^{20}$ Enquanto Elias apontou para os novos parâmetros de conduta que se espalharam entre os extratos sociais dominantes ao passo em que a sociedade capitalista e as relações comerciais se alastravam, evidenciando a importância da disciplina e da racionalidade no trabalho e condenando o predomínio da instintividade, Foucault escreveu sobre o mesmo processo, contudo em termos de uma vigilância e autoridade interna. Foucault analisou uma série de discursos e práticas, da criação da prisão para a criação da sexualidadee demonstrou como o "corpo", na sociedade ocidental moderna, se tornou um lugar de poderes constitutivos. Para ele o poder que certas instituições tais como prisões e hospícios, e também através das práticas que as constituem, definem-se por uma forma efetiva de poder e controle do indivíduo. (FOUCAULT, 1980).
} 
da questão do quão fundamentalmente diferente a personalidade africana era quando comparada com aquela do europeu.

Em termos metodológicos, os etnopsiquiatras formaram um grupo heterogêneo. Suas afiliações intelectuais variavam ecleticamente entre a eugenia e psicanálise. Todavia, compartilhavam de uma série de interesses comuns. Todos eram médicos contratados pelo governo colonial e, portanto, parte de uma minoria social dominante. Como intelectuais, sua posição minoritária era ainda mais exclusiva dentro da própria elite branca colonial. De forma geral, esses médicos supunham que seu trabalho estava desconectado dos interesses políticos. Eles não apresentavam qualquer relação formal com as políticas raciais estabelecidas nas colônias britânicas.

Não obstante, a etnopsiquiatria carrega consigo a ideia de que a vocação colonial era nobre e que algumas desabilidades sofridas pelos africanos precisavam ser seriamente consideradas. A literatura clínica explica aquilo que muitos colonos brancos acreditavam terminantemente: a personalidade dos africanos impunha limites que impediam a implantação de um governo democrático. Como visto, com o passar das décadas, as teorias psiquiátricas se apresentam mais favoráveis à existência de uma administração colonial europeia.

Nos anos em que as elites brancas possuíam o monopólio sobre os meios legítimos de praticar a violência sobre o sujeito nativo, a mesma era justificada pela necessidade de um trabalhador africano dócil e pacífico, capaz de se adaptar às diferentes formas de trabalho e de conformar as regras impostas no ambiente urbano colonial. Essa preocupação parece se refletir na expectativa apresentada pelos etnopsiquia tras em buscar o ideal de autocontrole no sujeito africano. Todavia, com a eminência do fim do poder colonial no período entre os anos 1920 e 1960, os colonos europeus demonstravam seu medo da possibilidade de terem que compartilhar o poder político com os nativos e sua ansiedade sobre a potencial violência africana, através de mitos como, por exemplo, o Black Peril.

A etnopsiquiatria refletiu essas tensões, ansiedades e preocupações dos colonos europeus. Os textos psiquiátricos idealizavam a sociedade e o homem europeu, sua capacidade de disciplina, contenção sexual, autocontrole, altruísmo e prestígio. Sua antítese era o sujeito africano e sua selvageria, violência, preguiça e promiscuidade. A ênfase na virtude do homem europeu branco e nos vícios do homem africano negro configura a retórica predominante no discurso etnocêntrico sobre a diferença e descreve os fundamentos da doutrina sobre a inferioridade africana.

Dentro da etnopsiquiatria, o termo "primitivo" era usado para caracterizar os africanos. No trabalho de Carothers, Gordon, Laubscher e Ritchie, esse primitivismo era evidente entre os nativos educados aos moldes ocidentais, que apresentavam distúrbios mentais resultantes do contato com o saber ocidental. Os africanos, sobre quem eles escreveram, 
eram aqueles intelectuais que contestaram o poder colonial e que, inclusive, se tornaram líderes da geração de nacionalistas. Eram definidos como deficientes em suas qualidades por serem incapazes, mais uma vez, de se submeterem ao trabalho disciplinado e se conformarem às regras.

A ciência da etnopsiquiatria foi inventada em nome de uma elite colonial em declínio, da qual os próprios etnopsiquiatras pertenciam. O conhecimento por ela produzido era, em si, um tanto quanto irrelevante para a comunidade colonial branca, quando apresentava dados já conhecidos pelos mesmos: os trabalhadores africanos são perigosos, preguiçosos e não confiáveis. $O$ papel dessa ciência se define como um meio de elevar esses estereótipos do campo da sátira para o campo da ciência. Carothers e seus contemporâneos ofereceram os subsídios teóricos para explicar as "falhas" e incompetências do sujeito africano diante do mundo civilizado. A etnopsiquiatria foi a resposta mais eloquente para o nacionalismo africano.

\section{Referências}

ABBAGNANO, Nicola. Dicionário de Filosofia. São Paulo: Martins Fontes, 2007.

CAROTHERS, J. C. A Study of Mental Derangement in Africans and an Attempt to Explain its Peculiarities, More Especially in Relation to the African Attitude to Life. The Journal of Mental Science, London, v. 93, p. 548-597, 1947.

. Frontal Lobe Function and the African. The Journal of Mental Science, London, v. 97, n. 406, p. 12-48, 1951.

_ _ _ _ _. Some Speculations on Insanity in Africans in General. East African Medical Journal, Nairobi, v. 17, p.90-105, 1940.

_. _ _ _. The African Mind in Health and Disease. Geneva: World Health Organization. 1953.

_ _ _ _ _. The Psychology of Mau Mau. Nairobi: Government Printer, 1954.

CHANOCK, Martin.Law, Custom and Social Order: the colonial experience in Malawi and Zambia. Cambridge: Cambridge University Press. 1987.

CLEARY, A. S. The Myth of Mau Mau in its International Context. African Affairs, London, v. 89, n. 355, p. 215-238, 1990. 
DECRAENE, Philippe. O Pan-Africanismo. São Paulo: Difusão europeia do livro, 1962.

DUBOW, Saul. Wulf Sach's Black Hamlet: A Case of Psychic Vivisection?. African Affairs, London, v. 92, p. 519-556, 1993.

EDGERTON, R. B. Mau Mau: An African Crucible. New York: Free Press, 1989.

ELIAS, Norbert. The Civilising Process: State Formation and Civilization. Oxford: Basil Blackwell. 1978.

FANON, Frantz. Pele negra, máscaras brancas. Salvador: EDUFBA. 2008.

_. - _ _. The North African Syndrome. In: _ _ _ _.. Toward the African Revolution.

Translation Haakon Chevalier. London: Pelican Books. 1967. p 13-26.

_. _ _ _. Madness and Civilization. London: Random House. 1989

_._. _ . . Michel Foucault: power and knowledge. Sussex: Hassocks. 1980.

FREUD, Sigmund. Totem and Taboo. Resemblances between the Psychic Lives of Savages and Neurotics. Translation A. A. Brill. New York: Vintage Books. 1946.

GERMAN, G. A. Mental Health in Africa 1. The extent of mental health problems in Africa today: An Update of Epidemiological Knowledge. British Journal of Psychiatry, London, v. 151, p. 435-439, 1987.

GILMAN, Sander. Difference and Pathology: Stereotypes of Sexuality, Race and Madness. New York: Ithaca. 1985.

GORDON, H. L. An Inquiry into the correlation of Civilization and Mental Disorders. East African Medical Journal, Nairobi, v. 12. p. 327-335. 1935-6

Editorial. East African Medical Journal, Nairobi, v. 3, n. 8, 1934.

HABTE, A.; WAGAW. Educação e mudança social. In: MAZRUI, Ali A. (Ed.). História geral da África. VIII: África desde 1935. Brasília: UNESCO, 2010. p. 817-844.

HARRIS, Joseph.E.; ZEGHIDOUR, Slimane. A África e a diáspora negra. In: MAZRUI, Ali. A. (Ed.). História Geral da África. VIII. Brasília: UNESCO, 2010. p.861-884.

HARRIS, J. E. A África e a diáspora negra. In: MAZRUI, Ali. A. (Ed.). História geral da África. VIII: África desde 1935. Brasília: UNESCO, 2010. p. 846-872. 
JACKSON, Will. Bad Blood: Poverty, Psychopathy and the Politics of Transgression in Kenya Colony, 1939-59. The Journal of Imperial and Commonwealth History, London, v. 39, n. 1, p. 73-94, 2011.

KELLER, R. Madness and Colonization: Psychiatry in the British and French Empires, 18001962. Journal of Social History, Pittsburgh, v. 35, n. 2, p. 295-321, 2001.

KIRBY, M. The Unhappiness of the Kikuyu: Or the Seeds of Mau Mau. East African Medical Journal, Nairobi, v. 10, p. 529-532, 1957.

LAUBSCHER, B. J. F. Sex, Custom and Psychopathology: A study of South African Pagan natives. London: George Routledge, 1937.

MANNONI, Octave. Prospero and Caliban. London: Oxford, 1956.

MCCULLOCH, J. Black Peril, White Virtue. Sexual Crime in Southern Rhodesia 1902-1935. Bloomington: Indiana University Press, 2000.

_. _ _ . . Colonial Psychiatry and "the African mind". Cambridge: Cambridge University Press, 1995.

_. - _ _. The Emperor's New Clothes: Ethnopsychiatry in Colonial Africa. History of the Human Sciences, London, v. 6, n. 2, p. 35-52, 1993.

ODA, A. M. G. R.; BANZATO, A. E. M.; DALGALARRONDO, P. Some origins of cross-cultural psychiatry. History of Psychiatry, London, v.16, n. 2, p. 155-169, 2005.

OGOT, B. A. (Ed.). Hadith 4: Politics and Nationalism in Colonial Kenya. Nairobi: East African Publishing House, 1972.

PAPE, J. Black and White: The Perils of Sex in ColonialZimbabwe. Journal of Southern African Studies, London, v. 16, n. 4, p. 31-49, 1990.

PHIRI, D. D. Malawians to Remember: John Chilembwe. Lilongwe: Longman, 1976.

POWER, Joey. Political culture and nationalism in Malawi: building Kwacha. New York:

University of Rochester Press, 2010.

RITCHIE, J. F. The African as Suckling and as Adult: A Psychological Study. Manchester: Manchester University Press. 1968.

ROUSSEAU, Jean-Jacques. Do contrato social [1762]. Ensaio sobre a origem das línguas. São Paulo: Abril Cultural, 1978. (Coleção Os Pensadores). 
. Discurso sobre a origem e os fundamentos da desigualdade entre os homens [1755];

Discurso sobre as ciências e as artes [1750]. São Paulo: Martins Fontes, 1993.

SADOWSKY, Jonathan. Psychiatry and Colonial Ideology in Nigeria. Bulletin of the History of Medicine, Baltimore, v.71, n. 1, p. 94-111, 1997.

SHELLEY, H.; WATSON, H. W. An Investigation Concerning Mental Disorder in the Nyasaland natives. The Journal of Mental Science, London, v. 82, p. 702-725, 1936.

SIMONS, H. J. Mental Disease in Africans: Racial Determinism. The Journal of Mental Science, London, v. 104, p. 377-88, 1985.

VAUGHAN, Megan. Curing Their Ills: Colonial Power and African Illness. Stanford: Stanford University Press. 1991.

. Idioms of Madness: Zomba Lunatic Asylum, Nyasaland, in the Colonial Period. Journal of Southern Africa Studies, London, v. 9, n. 2, p. 218-238, 1983.

VINT, F. W. A Preliminary Note on the Cell Content of the Prefrontal Cortex of the East African Native. East African Medical Journal, Nairobi, v. 9, p. 30-55, 1932-1933.

WILKINSON, J. The Mau Mau Movement: Some General and Medical Aspects. East African Medical Journal, Nairobi, v. 7, p. 294-314, 1954.

Recebido em 08.01.2015

Aprovado em 22.09.2015 